\title{
ANALISIS PERAMALAN TINGKAT JUMLAH TAMU MENGINAP MENGGUNAKAN METODE SINGLE EXPONENTIAL SMOOTHING DI VILLA X DI DESA GOBLEG, KABUPATEN BULELENG TAHUN 2018
}

\author{
Kadek Sri Krisna Dewi ${ }^{1}$, Kadek Rai Suwena ${ }^{2}$ \\ Jurusan Pendidikan Ekonomi \\ Universitas Pendidikan Ganesha \\ Singaraja, Indonesia
}

Email: kadeksrikrisna.dewi@yahoo.com ${ }^{1},{\text { kadek.suwena@undiksha.co.id1 }{ }^{2}}^{2}$

\begin{abstract}
Abstrak
Penelitian ini bertujuan untuk mengetahui tingkat jumlah tamu menginap di Villa $X$ tahun 2013 - 2017 dan kecenderungan tingkat jumlah tamu menginap dengan menggunakan metode single exponential smoothing di Villa $X$ tahun 2018. Jenis penelitian ini adalah penelitian deskriptif. Data dikumpulkan dengan metode dokumentasi dan wawancara. Analisis data yang digunakan adalah analisis deret waktu (time series) dengan menggunakan metode single exponential smoothing. Hasil penelitian menunjukkan bahwa tingkat jumlah tamu menginap di Villa $X$ tahun 2013 - 2017 mengalami fluktuasi. Tingkat jumlah tamu menginap paling tinggi terjadi pada tahun 2015 sebanyak 3.283 orang dan tingkat jumlah tamu menginap paling rendah terjadi pada tahun 2013 dengan tingkat jumlah tamu menginap sebesar 2.330 orang sedangkan kecenderungan tingkat jumlah tamu menginap dengan menggunakan metode single exponential smoothing di Villa $X$ tahun 2018 mengalami fluktuasi, tingkat jumlah tamu menginap sebanyak 2.918 orang. Tingkat jumlah tamu menginap tertinggi terjadi pada bulan Agustus sebanyak 389 orang sedangkan tingkat jumlah tamu menginap terendah terjadi pada bulan November sebanyak 119 orang.
\end{abstract}

Kata kunci: single exponential smoothing, tingkat jumlah tamu menginap.

\begin{abstract}
This research is aimed to find the increase number of guest on Villa $X$ from 2013 until 2017 and the tendency of guest who used single exponential smoothing method in Villa X on 2018. This research is descriptive research. The data was collected by using documentation and interview method. Data analysis was done by using time series data analysis with single exponential smoothing method. The result of the data analysis shows that the tendency of guest on Villa from 2013 until 2017 is fluctuating. The highest tendency of guest are showed on 2015, it was 3.283 guest and the lowest tendency of guest are showed on 2013 which has 2.330 guest, in the other hand, the tendency of guest who used single exponential smoothing method in Villa on 2018 is fluctuating into 2.918 guest. The highest number of guest is showed up on August which is 339 guest and the lowest number of guest showed up on November which has 119 guest.
\end{abstract}

Key word : single exponential smoothing, tendency of guest..

\section{PENDAHULUAN}

Perusahaan memiliki tiga bidang didalam menjalankan usahanya yaitu perusahaan dagang, jasa dan industri. Dimana salah satu perusahaan jasa adalah usaha akomodasi yaitu Villa, yang merupakan salah satu dari jenis-jenis akomodasi komersial. Menurut Devi (2016), akomodasi komersial adalah akomodasi yang didirikan dan disusun hanya bertujuan untuk mendapatkan profit atau mencari keuntungan yang besar. Menurut Undang- 
undang RI No. 10 tahun 2009, industri pariwisata merupakan kumpulan usaha pariwisata yang saling terkait dalam rangka menghasilkan barang dan jasa bagi pemenuhan kebutuhan wisatawan dalam penyelenggaraan pariwisata. Usaha dibidang perhotelan sangat populer dikalangan para wisatawan karena sarana untuk memfasilitasi wisatawan untuk menginap.

Dalam dunia usaha manajemen sangat diperlukan dalam mencapai tujuan, manajemen merupakan suatu proses yang melibatkan kegiatan perencanaan, pengorganisasian, pengarahan, dan pengendalian yang dilakukan untuk mencapai sasaran perusahaan melalui pemanfaatan sumber daya manusia dan sumber daya lainnya (Fuad, dkk, 2000:92). Salah satu fungsi dari manajemen adalah perencanaan, menurut Wilson perencanaan merupakan salah satu proses lain, atau merubah suatu keadaan untuk mencapai mksud yang dituju oleh perencanaan atau oleh orang/badan yang diwakili oleh perencanaan itu. Dalam mengambil suatu keputusan perusahaan harus melakukan suatu perencanaan yang tepat dan matang yang sesuai dengan tujuan yang diinginkan oleh suatu perusahaan. Selain kata perencanaan, ada salah satu kata yang tidak asing yaitu peramalan. Peramalan merupakan bagian dari perencanaan itu sendiri, dimana sebelum mengambil keputusan dalam membuat suatu perencanaan, sebaiknya terlebih dahulu melakukan peramalan. Karena dengan melakukan peramalan perusahaan dapat memperoleh informasi mengenai perubahan dimasa yang akan datang.

$$
\text { Menurut }
$$

Wignjosoebroto

(2003:337), peramalan merupakan suatu upaya untuk memperoleh gambaran mengenai keadaan suatu perusahaan pada masa yang akan mendatang. Ramalan tersebut sangat penting bagi perusahaan karena perusahaan bisa memprediksi langkah-langkah apa saja yang diambil dalam memenuhi keinginan dari konsumen. Ramalan memang tidak selalu tepat $100 \%$, akan tetapi dengan pemilihan metode yang tepat dapat membuat peramalan dengan tingkat kesalahan yang kecil. $\begin{array}{crr}\text { Menurut } & \text { Nasution \& } & \text { Prasetyawan } \\ \text { (2008:29), } & \text { peramalan } & \text { adalah } \\ \text { memperkirakan } & \text { beberapa } & \text { kebutuhan }\end{array}$ dimasa datang yang meliputi kebutuhan dalam ukuran kuantitas, kualitas, waktu dan lokasi yang dibutuhkan dalam rangka memenuhi barang atau jasa. Lebih lanjut menurut Ishak (2010:104), peramalan merupakan bagian awal dari suatu proses pengambilan suatu keputusan. Dari pengertian diatas dapat disimpulkan bahwa peramalan merupakan suatu usaha untuk meramalkan keadaan dimasa yang akan datang dengan pengujian keadaan dimasa lalu dan untuk pengambilan keputusan. Aktivitas peramalan merupakan bagian yang sangat penting dari perencanaan karena dengan peramalan yang akurat maka sumber daya akan dapat dialokasikan dengan efektif dan efisien.

Menurut Ishak (2010:107), pentingnya peramalan bagi tingkat jumlah tamu menginap adalah sebagai upaya untuk memperkecil risiko yang timbul akibat pengambilan keputusan dalam suatu perencanaan produksi. Semakin besar upaya yang dikeluarkan tentu risiko yang dapat dihindari semakin besar pula. Faktorfaktor yang dipertimbangkan yaitu, horizon peramalan, tingkat ketelitian, ketersediaan data, bentuk pola data, biaya, jenis dari model, mudah tidaknya penggunaan dan aplikasinya.

Upaya memperkecil risiko tersebut dibatasi oleh biaya yang dikeluarkan akibat mengupayakan hal tersebut. Dalam sistem peramalan, penggunaan berbagai model peramalan akan memberikan nilai ramalan yang berbeda dan derajat dari galat peramalan yang berbeda pula. Salah satu seni dalam melakukan peramalan adalah memilih model peramalan yang terbaik yang mampu mengidentifikasi dan menanggapi pola aktivitas historis dari data.

Dalam membuat peramalan atau menerapkan suatu peramalan maka ada beberapa hal yang harus dipertimbangkan yaitu. ramalan pasti mengandung kesalahan, artinya peramalan hanya bisa mengurangi ketidakpastian yang akan terjadi, tetapi tidak dapat menghilangkan ketidakpastian tersebut, peramalan seharusnya memberikan informasi tentang beberapa ukuran kesalahan, artinya karena 
peramalan pasti mengandung kesalahan, maka adalah penting bagi peramal untuk menginformasikan seberapa besar kesalahan yang mungkin terjadi, dan peramalan jangka pendek lebih akurat dibandingkan peramalan jangka panjang. Hal ini disebabkan karena pada peramalan jangka pendek, faktor-faktor yang mempengaruhi permintaan relatif masih konstan sedangkan masih panjang periode peramalan, maka semakin besar pula kemungkinan terjadinya perubahan faktorfaktor yang mempengaruhi permintaan.

Pada umumnya peramalan dapat dibedakan dari beberapa segi tergantung dari cara melihatnya Apabila dilihat dari penyusunannya, maka peramalan dapat dibedakan atas dua macam, yaitu metode peramalan kualitatif dan metode peramalan kuantitatif.

Peramalan kualitatif umunya bersifat subjektif, dipengaruhi oleh intuisi, emosi, pendidikan, dan pengalaman seseorang. Oleh karena itu, hasil peramalan dari satu orang dengan orang yang lain dapat berbeda. Meskipun demikian, peramalan dengan metode kualitatif tidak berarti hanya menggunakan intuisi, tetapi juga bisa mengikutsertakan model-model statistik sebagai bahan masukan dalam melakukan judgement (keputusan), dan dapat dilakukan secara perseorangan maupun kelompok.

Pada dasarnya metode peramalan kuantitatif ini dapat dibedakan atas dua bagian, yaitu. Metode peramalan yang didasarkan atas penggunaan analisa pola hubungan antara variabel yang akan diperkirakan dengan variabel waktu, yang merupakan deret waktu atau "time series". Dan metode peramalan yang didasarkan atas penggunaan analisa pola hubungan antara variabel yang akan diperkirakan dengan variabel lain yang mempengaruhinya, yang bukan waktu yang disebut metode korelasi atau sebab akibat (causal method).

Menurut Fahmi, (2014:161) proses peramalan biasanya terdiri dari langkahlangkah sebagai berikut. penentuan tujuan. Langkah pertama terdiri atas penentuan macam estimasi yang diinginkan. Analis membicarakan dengan para pembuat keputusan untuk mengetahui apa kebutuhan-kebutuhan mereka, dan menentukan, pengembangan model. Dalam peramalan, model adalah suatu kerangka analitik yang, bila dimasukan data masukan, menghasilkan estimasi penjualan di waktu mendatang (atau variabel apa saja yang diramal), pengujian model. Nilai suatu model ditentukan oleh derajat ketepatan hasil peramalan dengan kenyataan, penerapan model. Setelah pengujian, analisis menerapkan model dalam tahap ini, data historik dimasukkan dalam model untuk menghasilkan suatu ramalan, dan revisi dan evaluasi. Perbaikan mungkin perlu dilakukan karena adanya perubahanperubahan dalam perusahaan atau lingkungannya, seperti tingkat harga produk perusahaan, karakteristik-karakteristik produk, pengeluaran pengiklanan, tingkat pengeluaran pemerintah, kebijaksanaan moneter dan kemajuan teknologi.

Ukuran akurasi hasil peramalan yang merupakan ukuran kesalahan peramalan merupakan ukuran tentang tingkat perbedaan antara hasil peramalan dengan permintaan yang sebenarnya terjadi. Ada empat ukuran yang biasa digunakan, yaitu rata-rata deviasi mutlak, rata-rata kuadrat kesalahan, rata-rata kesalahan peramalan, dan rata-rata persentase kesalahan absolut (Nasution \& Prasetyawan, 2008:34).

Menurut Nasution \& Prasetyawan

(2008:61), Langkah penting setelah peramalan dibuat adalah melakukan verifikasi peramalan sedemikian rupa sehingga hasil peramalan tersebut benarbenar mencerminkan data masa lalu dan sistem sebab akibat yang mendasari permintaan tersebut. Sepanjang aktualitas peramalan tersebut dapat dipercaya, hasil peramalan akan terus digunakan. Jika selama proses verifikasi tersebut ditemukan keraguan validitas metode peramalan yang digunakan, harus dicari metode lainnya yang lebih cocok. Validitas tersebut harus ditentukan dengan uji statistika yang sesuai. Banyak alat yang dapat digunakan untuk memverifikasi peramalan dan mendeteksi perubahan sistem sebab akibat yang melatar belakangi perubahan pola permintaan. Bentuk yang paling sederhana adalah peta kontrol peramalan yang mirip dengan peta kontrol kualitas. Peta kontrol 
peramalan ini dapat dibuat dengan dalam kondisi data yang tersedia minim.

Menurut Handoko (2012), Metode time series adalah metode yang dipergunakan untuk menganalisis serangkaian data yang merupakan fungsi dari waktu. Metode ini mengasumsikan beberapa pola atau kombinasi pola selalu berulang sepanjang waktu, dan pola dasarnya dapat diidentifikasi semata-mata atas dasar data historis dari serial itu. Dengan analisis deret waktu dapat ditunjukkan bagaimana permintaan terhadap suatu produk tertentu bervariasi terhadap waktu. Sifat dari perubahan permintaan dari tahun ke tahun dirumuskan untuk meramalkan penjualan pada masa yang akan datang. Adapun metode peramalan yang termasuk model time series yaitu metode penghalusan, metode proyeksi kecenderungan dengan regresi, dan metode dekomposisi (Ishak, 2010:124)

Menurut Assauri (2016:88), Metode exponential smoothing adalah suatu teknik rata-rata bergerak yang rumit, yang secara relatif masih mudah untuk digunakan dan dipahami. Teknik ramalan ini, pada dasarnya adalah suatu teknik perkiraan ramalan rata-rata bergerak yang tertimbang, dengan suatu fungsi exponential pada titik data yang tertimbang. Teknik prakiraan ramalan exsponential smoothing, walaupun pada dasarnya dirumitkan oleh rata-rata bergerak tertimbang, tetapi dalam penggunaannya masih mudah. Dalam teknil prakiraan ramalan ini menggunakan catatan data yang lalu yang lebih sedikit.

Menurut Ishak (2010:126), pengertian dasar dari metode single exponentia smoothing adalah nilai ramalan pada periode $t+1$ merupakan nilai aktual pada periode $t$ ditambah dengan penyesuaian yang berasal dari kesalahan nilai ramalan yang terjadi pada periode tersebut.

Menurut Render \& Heizer (2005), metode ini membutuhkan nilai alpha (a) sebagai nilai parameter pemulusan. Bobot nilai a lebih tinggi diberikan kepada data yang lebih baru, sehingga nilai parameter a yang sesuai akan memberikan ramalan yang optimal dengan nilai kesalahan (error) terkecil. Untuk mendapatkan nilai a yang tepat pada umumnya dilakukan dengan trial and error (coba-coba) untuk menentukan nilai kesalalahan terendah. Nilai a dilakukan dengan membandingkan menggunakan interval pemulusan antara $0<a<1$, yaitu a $(0,1$ sampai dengan 0,9$)$. Metode ini hanya mampu memberikan ramalan satu periode ke depan dan cocok untuk data yang mengandung unsur stationer. Karena jika diterapkan pada serial data yang memiliki trend yang konsisten, metode exponential ini juga memberikan bobot yang relatif lebih tinggi pada nilai pengamatan terbaru dibanding nilai-nilai periode sebelumnya Metode peramalan merupakan cara memperkirakan apa yang akan terjadi pada masa yang akan datang secara sistematis dan pragmatis, sehingga metode peramalan sangat berguna untuk dapat memperkirakan secara sistematis dan pragmatis atas dasar data yang relevan pada masa yang lalu, dengan demikian metode peramalan diharapkan dapat memberikan objektivitas yang lebih besar. Disamping itu metode peramalan juga memberikan urutan pengerjaan dan pemecahan atas pendekatan suatu masalah dalam peramalan, sehingga bila digunakan pendekatan yang sama atas permasalahan dalam suatu kegiatan peramalan, maka akan didapat dasar pemikiran dan pemecahan yang sama, karena argumentasinya sama. Selain itu, metode peramalan memberikan cara pengerjaan yang teratur dan terarah, sehingga dengan demikian dapat dimungkinkannya penggunaan teknik-teknik penganalisaan yang lebih maju. Dengan penggunaan teknik-teknik tersebut, maka diharapkan dapat memberikan tingkat kepercayaan dan keyakinan yang lebih besar, karena dapat diuji dan dibuktikan penyimpangan atau devisiasi yang terjadi secara ilmiah.

Menurut Ishak (2010:115) metode perhitungan peralaman ada dua yaitu, metode peramalan kualitatif dan metode kuantitatif. Selain dari dua metode tersebut ada juga metode time series yaitu, metode rata-rata bergerak (moving average), metode exponential smoothing, dan metode kausal. Dimana metode peramalan sangat berguna, untuk membantu dalam mengadakan pendekatan analisa terhadap tingkah laku atau pola dari data yang lalu 
sehingga dapat memberikan cara pemikiran, pengerjaan dan pemecahan yang sistematis dan pragmatis, serta memberikan tingkat keyakinan yang lebih besar atas ketepatan hasil ramalan yang dibuat atau yang disusun.

Villa $X$ adalah resor alam yang mewah, spa dan hotel di Bali Utara diperkebunan kopi yang terletak di dekat danau pusat Bali dan stasiun bukit munduk. Luas lahan Villa tersebut mencapai 5 hektar, yang terletak kawasan indah munduk, Singaraja Buleleng Bali. Resort dan Spa ini terletak di Banjar Dinas Asa, Desa Gobleg, Kecamatan Banjar, Buleleng. Villa X memiliki fasilitas dari masing-masing kamar yang cukup lengkap diantaranya : paket selamat datang, teras pribadi, telpon genggam pribadi, CD, ipod, DVD plyer, TV layar datar, pengering rambut, fasilitas membuat teh dan kopi, jubah mandi, sandal, air botol, mini bar, meja tulis, perlengkapan mandi, dan kotak keselamatan. Villa ini menyediakan berbagai jenis kamar yaitu : garden suite, villa, one bedroom pool villa, two bedroom coffe villa, two bedroom pool villa, four bedroom pool villa. Selain memiliki fasilitas yang cukup lengkap villa ini juga menyediakan pelayanan yang sangat lengkap dengan mengutamakan kepuasaan dari pelanggan. Berbicara tentang villa, tentu saja yang menjadi produk utamanya adalah para wisatawan, dimana para wisatawan menjadi salah satu faktor utama untuk melakukan kegiatan liburan di villa guna menambah keuntungan yang akan di dapat oleh villa itu sendiri.

Pada penelitian awal, dapat dilihat bahwa masalah yang dihadapi oleh Villa $X$ selama lima tahun terakhir adalah tiap tahun tingkat jumlah tamu menginap selalu mengalami peningkatan dan penurunan. Tepatnya tingkat jumlah tamu menginap tahun 2013 sebesar (55.84\%), tahun 2014 (67.15\%), tahun 2015 (78.67\%), tahun 2016 (82.17\%), tahun 2017 (66.95\%). Dari persentase hasil jumlah tamu menginap di Villa $X$ yang mengalami peningkatan adalah pada tahun 2015 sebesar $78.67 \%$ dan tahun 2016 sebesar 82.17\%, sedangkan pada tahun 2013, 2014, dan 2017 mengalami penurunan. Sebuah Villa membutuhkan perencanaan yang matang terhadap jumlah tamu yang menginap dengan menggunakan metode peramalan yang tepat guna untuk memprediksi hasil tingkat jumlah tamu menginap di Villa dimasa yang akan datang, agar dapat memberikan keuntungan yang maksimal. Peramalan digunakan sebagai bahan pertimbangan untuk mengambil keputusan yang tepat, agar keputusan yang diambil tidak salah nantinya, sehingga Villa membutuhkan infomasi yang realistis dan terstruktur dengan rapi. Dengan peramalan yang dibuat, diharapkan dapat memberikan informasi mengenai keadaan yang akan terjadi dimasa mendatang. Sehingga perusahaan jasa seperti Villa dapat lebih tepat dalam pengambilan keputusan manajemen yang berkaitan dengan masalah tingkat tamu menginap. Untuk memperkirakan tingkat jumlah tamu menginap, villa ini hanya melakukan perkiraan secara tradisional dan tidak menggunakan metode sesuai dengan teori dari peramalan.

Dari uraian tersebut, peneliti tertarik untuk meneliti tingkat jumlah tamu dengan mengangkat judul "Analisis Peramalan Tingkat Jumlah Tamu Menginap Menggunakan Metode Single Exponential Smoothing Di Villa X Di Desa Gobleg, kabupaten Buleleng Tahun 2018".

\section{METODE}

Penelitian ini termasuk dalam jenis penelitian deskripstif. Penelitian deskriptif merupakan penelitian yang dilakukan untuk mengetahui nilai masing-masing variabel, baik satu variabel atau lebih sifatnya independen tanpa membuat hubungan maupun perbandingan dengan variabel yang lain (Sujarweni,2014:11). Penelitian ini dilakukan untuk mengetahui peramalan tingkat jumlah tamu menginap dengan menggunakan data time series. Peramalan tingkat jumlah tamu menginap dengan menggunakan metode single exponential smoothing menggunakan rumus $\mathrm{F}_{\mathrm{t}+1}=\mathrm{a} \mathrm{X}_{1}$ $+\left(1-\right.$ a) $F_{t-1}$. nilai alpha yang digunakan dalam metode ini $a=0.5$, dan data yang digunakan adalah lima tahun terakhir 2013 - 2017. Penelitian ini berlokasi di jalan Raya Asah Gobleg Banjar Dinas Asah Desa Gobleg, Kecamatan Banjar, Buleleng. 
Subjek dalam penelitian ini adalah Villa X. Objek dari penelitian ini adalah data jumlah tingkat tamu menginap lima tahun terakhir (2013 - 2017).

Jenis data dalam penelitian ini adalah menggunakan data kuantitatif. Data kuantitatif yang diperoleh dalam penelitian ini yaitu tingkat jumlah tamu menginap dari tahun 2013 - 2017. Sedangkan sumber data yang digunakan dalam penelitian ini adalah data primer dan data sekunder. Data primer adalah data yang langsung berkaitan dengan objek penelitian. Data yang diperoleh dengan cara mengajukan wawancara dengan mengajukan pertanyaan terkait tentang tingkat jumlah tamu menginap dari tahun 2013 - 2017. Data sekunder berupa catatan bulanan dan tahunan tingkat jumlah tamu menginap dari tahun $2013-2017$.

Metode pengumpulan data yang digunakan dalam penelitian ini adalah dokumentasi dan wawancara. Dokumentasi dilakukan dengan mengamati dokumendokumen atau catatan-catatan yang tersimpan di Villa X. Data yang diperoleh melalui teknik dokumentasi berupa catatan tingkat jumlah tamu menginap dari tahun 2013 - 2017. Wawancara adalah teknik pengumpulan data dengan melakukan tanya jawab dengan pihak-pihak terkait dengan tujuan penelitian dan untuk mencari penjelasan mengenai data yang hendak diteliti yaitu tingkat jumlah tamu menginap dari tahun 2013 - 2017.

Metode analisis data yang digunakan dalam penelitian ini adalah analisis deret waktu (time series), yaitu data yang dikumpulkan dari waktu ke waktu untuk menggambarkan kejadian dimasa yang akan datang (Supranto, 2000:214). Data time series dalam penelitian ini adalah data tingkat jumlah tamu menginap dari tahun 2013 - 2017. Peramalan tingkat jumlah tamu menginap dengan dengan menggunakan data time series dengan metode single exponential smoothing. Menurut Ishak (2010:126), pengertian dasar dari metode ini adalah nilai ramalan pada periode $t+1$ merupakan nilai aktual pada periode $\mathrm{t}$ ditambah dengan penyesuaian yang berasal dari kesalahan nilai ramalan yang terjadi pada periode tersebut. Nilai peramalan dapat dicari dengan menggunakan rumus berikut.

$F_{t+1}=a X_{1}+(1-a) F_{t-1}$.

(Ishak, 2010)

Keterangan:

$\mathrm{Ft}+1=$ Ramalan untuk periode ke $\mathrm{t}+1$

$\mathrm{Xt} \quad=$ Nilai rill periode ke $\mathrm{t}$

a =Bobot yang menunjukan konstanta penghalus $(0<a<1)$

$\mathrm{Ft}-1=$ Ramalan untuk periode ke $\mathrm{t}-1$

\section{HASIL DAN PEMB AHASAN}

\section{HASIL}

Tingkat Jumlah Tamu Menginap Di

Villa X Tahun 2013-2017

Villa $X$ adalah resor alam yang mewah, spa dan hotel di Bali Utara diperkebunan kopi yang terletak di dekat danau pusat Bali dan stasiun bukit munduk. Luas lahan villa tersebut mencapai 5 hektar, yang terletak kawasan indah munduk, Singaraja Buleleng Bali. Resort dan spa ini terletak di Banjar Dinas Asa, Desa Gobleg, Kecamatan Banjar, buleleng. Villa ini juga menyediakan berbagai jenis kamar yaitu : garden suite, villa, one bedroom pool villa, two bedroom coffee villa, two bedroom pool villa, four bedroom pool villa. Selain memiliki fasilitas yang cukup lengkap villa ini juga menyediakan pelayanan yang sangat lengkap dengan mengutamakan kepuasaan dari pelanggan.

Selama lima tahun terakhir tingkat jumlah tamu menginap pada Villa $X$ mengalami peningkatan dan penurunan. Yang menyebabkan Villa tersebut mengalami masalah adalah karena adanya tingkat jumlah tamu yang datang tidak stabil, sebuah Villa membutuhkan perencanaan yang sangat matang terhadap jumlah tamu yang menginap dengan menggunakan metode peramalan yang tepat guna untuk memperediksi hasil tingkat jumlah tamu menginap dimasa yang akan datang, agar dapat memberikan keuntungan yang maksimal. Selain itu, Villa juga menyediakan pelayanan yang cukup memuaskan dengan mengedepankan pola kebersamaan dan tali manajemen kasih yang terbuka luas untuk seluruh karyawan. Tingkat jumlah tamu menginap di Villa $X$ tahun 2013-2017 dapat dilihat pada tabel 1. 
Tabel 1 Tingkat jumlah tamu menginap di Villa X Tahun 2013-2017

\begin{tabular}{cccccc}
\hline \multirow{2}{*}{ Bulan } & \multicolumn{5}{c}{ Tingkat Jumlah Tamu Menginap Tahun $2013-2017$ (Orang) } \\
& 2013 & 2014 & 2015 & 2016 & 2017 \\
\hline Januari & 91 & 152 & 180 & 170 & 200 \\
Februari & 72 & 170 & 269 & 204 & 209 \\
Maret & 152 & 158 & 162 & 195 & 290 \\
April & 172 & 218 & 221 & 194 & 170 \\
Mei & 217 & 244 & 273 & 232 & 333 \\
Juni & 208 & 236 & 273 & 261 & 268 \\
Juli & 292 & 334 & 397 & 407 & 355 \\
Agustus & 292 & 343 & 432 & 300 & 400 \\
September & 282 & 291 & 377 & 200 & 250 \\
Oktober & 270 & 282 & 324 & 170 & 170 \\
November & 157 & 211 & 206 & 286 & 102 \\
Desember & 125 & 163 & 169 & 294 & 129 \\
Jumlah & 2330 & 2802 & 3283 & 2913 & 2876 \\
\hline
\end{tabular}

Sumber : Data Villa $\mathrm{X}$

Berdasarkan tabel 1 dapat dijelaskan bahwa tingkat jumlah tamu menginap dari tahun 2013 - 2017 berfluktuasi. Total tingkat jumlah tamu menginap dari tahun 2013 sampai dengan 2017 sebanyak 14.204 orang. Tingkat jumlah tamu menginap pada tahun 2013 sebanyak 2.330 orang dan pada tahun 2014 sebanyak 2.802 orang, mengalami peningkatan sebanyak 472 orang. Tahun 2014 sebanyak 2.802 orang ke tahun 2015 mengalami peningkatan sebanyak 481 orang sehingga tingkat jumlah tamu menginap pada tahun 2015 sebanyak 3.283. Pada tahun 2016 sebanyak 2.913 orang mengalami penurunan 2015 sebanyak 370 orang serta tahun 2017 sebanyak 2.876 orang mengalami penurunan kembali sebanyak 37 orang. Tingkat jumlah tamu menginap paling tinggi terjadi pada tahun 2015 sebanyak 3.283 orang dan tingkat jumlah tamu menginap paling rendah terjadi pada tahun 2013 dengan tingkat jumlah tamu menginap sebesar 2.330 orang.

Tahun 2014 Tingkat jumlah tamu menginap tertinggi terjadi pada bulan Agustus sebanyak 343 orang dan tingkat jumlah tamu paling rendah yaitu terjadi pada bulan Januari sebanyak 152 orang. Tahun 2015 tingkat jumlah tamu menginap paling tinggi terjadi pada bulan Agustus sebanyak 432 orang dan tingkat jumlah tamu menginap paling rendah terjadi pada bulan Maret sebanyak 162 orang. Tahun 2016 Tingkat jumlah tamu menginap paling tinggi terjadi pada bulan Juli sebanyak 407 orang dan tingkat jumlah tamu menginap paling rendah terjadi pada bulan Januari dan bulan Oktober sebanyak 170 orang sedangkan tahun 2017 tingkat jumlah tamu menginap paling tinggi terjadi pada bulan Agustus sebanyak 400 orang dan tingkat jumlah tamu menginap paling rendah terjadi pada bulan November sebanyak 102 orang. Secara umum tingkat jumlah tamu menginap selama lima tahun setiap bulannya berfluktuasi.

Kecenderungan Tingkat Jumlah

Tamu Menginap Dengan Menggunakan Metode Single Exponential Smoothing Di Villa X Tahun 2018

Berdasarkan tabel 1 dapat dilihat bahwa tingkat jumlah tamu menginap mengalami fluktuasi dari bulan ke bulan yang terjadi pada tahun 2013-2017.

Untuk itu metode yang sesuai digunakan untuk meramal adalah metode single exponential smoothing.

$F_{t+1}=a X_{1}+(1-a) F_{t-1}$

(Ishak, 2010)

Dimana :

$\mathrm{F}_{\mathrm{t}+1}=$ Ramalan untuk periode ke $\mathrm{t}+1$

$\mathrm{X}_{\mathrm{t}} \quad=$ Nilai riil periode $\mathrm{ke} \mathrm{t}$

$\mathrm{a}=$ Bobot yang menunjukan

konstanta penghalus $(0<\mathrm{a}<1)$

$\mathrm{F}_{\mathrm{t}-1}=$ Ramalan untuk periode ke $\mathrm{t}-1$ 
Dalam peramalan ini, alpha (a) yang akan dicoba gunakan dalam metode ini adalah $\mathrm{a}=0.5$, dimana $\mathrm{F} 1=$ peramalan pada periode pertama belum tersedia, maka untuk mengatasi masalah ini dapat dilakukan dengan menetapkan nilai $F 1$ sama dengan nilai data periode pertama. Hasil jumlah tamu menginap tahun 2013-2017 dapat dilihat pada tabel 2.

Tabel 2 Hasil Jumlah Tamu 2013 - 2017

\begin{tabular}{|c|c|c|c|}
\hline No & Tahun & Hasil Jumlah Tamu/Tahun & $\begin{array}{l}\text { Hasil Peramalan/Tahun } \\
\mathrm{F}_{\mathrm{t}+1}=\mathrm{a} \mathrm{X}_{1}+(1-\mathrm{a}) \mathrm{F}_{\mathrm{t}-1}\end{array}$ \\
\hline 1 & 2013 & 2330 & 2222 \\
\hline 2 & 2014 & 2802 & 2783 \\
\hline 3 & 2015 & 3283 & 3280 \\
\hline 4 & 2016 & 2913 & 2851 \\
\hline 5 & 2017 & 2876 & 2959 \\
\hline \multicolumn{2}{|c|}{$\Sigma$} & 14204 & 14095 \\
\hline
\end{tabular}

Dari hasil peramalan pada tahun 2018

dapat dilihat pada tabel 3 .

.Tabel 3 Hasil Peramalan Tahun 2018

\begin{tabular}{cccc}
\hline No & Bulan & Peramalan & Peramalan (dibulatkan) \\
\hline 1 & Januari & 224 & 224 \\
2 & Februari & 206.75 & 207 \\
3 & Maret & 269.75 & 270 \\
4 & April & 200 & 200 \\
5 & Mei & 292.25 & 292 \\
6 & Juni & 284.25 & 284 \\
7 & Juli & 333.25 & 333 \\
8 & Agustus & 388.75 & 389 \\
9 & September & 288 & 288 \\
10 & Oktober & 190 & 190 \\
11 & November & 119 & 119 \\
12 & Desember & 122.25 & 122 \\
& Total & 2.918 .25 & 2.918 \\
\hline
\end{tabular}

Dari hasil perhitungan peramalan tahun 2018 dapat disimpulkan bahwa mengalami peningkatan dan penurunan setiap bulannya dan hasil keseluruhannya

\section{Pembahasan}

Hasil peramalan tingkat jumlah tamu menginap tahun 2018 mengalami fluktuasi, dimana bulan Januari diperkirakan jumlah tamu yang datang sebanyak 224 orang, bulan Februari sebanyak 206.75 orang dibulatkan menjadi 207 orang, bulan Maret sebanyak 269.75 dibulatkan menjadi 270 orang, bulan April sebanyak 200 orang, bulan Mei sebanyak 292.25 orang dibulatkan menjadi 292 orang, bulan Juni sebanyak 284.25 orang dibulatkan menjadi 284 orang, bulan Juli sebanyak 333.25 orang dibulatkan menjadi 333 orang, bulan adalah 2.918 orang. Hasil perhitungan peramalan tahun 2018 dapat dirumuskan ramalan baru $=$ ramalan periode lalu $+a$ (permintaan aktual periode yang lalu ramalan periode yang lalu).

Agustus sebanyak 388.75 orang dibulatkan menjadi 389 orang, bulan September sebanyak 288 orang, bulan Oktober sebanyak 190 orang, bulan November sebanyak 119 orang dan bulan Desember sebanyak 122.25 orang dibulatkan menjadi 122 orang, jadi total keseluruhan yang diperkirakan akan datang sebanyak 2.918.25 orang dibulatkan menjadi 2.918 orang. Dari tiap bulan yang diperkirakan memiliki selisih terhadap tahun sebelumnya yaitu tahun 2017, selisih pada bulan Januari sebanyak 24 orang, bulan Februari sebanyak 2 orang, bulan Maret sebanyak 
20 orang, bulan April sebanyak 30 orang, bulan Mei sebanyak 41 orang, bulan Juni sebanyak 16 orang, bulan Juli sebanyak 22 orang, bulan Agustus sebanyak 11 orang, bulan September sebanyak 38 orang, bulan Oktober sebanyak 20 orang, bulan November sebanyak 17 orang, bulan Desember sebanyak 7 orang.

Kecenderungan naik dan turunnya tingkat jumlah tamu menginap terjadi dalam rentang waktu dari tahun 2018 tersebut membuat gerakan naik turun atau berfluktuasi. Dari tahun 2018 yang mengalami tingkat jumlah tamu menginap tertinggi terjadi pada bulan Agustus sebanyak 389 orang sedangkan tingkat jumlah tamu menginap terendah terjadi pada bulan November sebanyak 119 orang. Hasil tersebut terjadi karena tingkat jumlah tamu menginap dari bulan ke bulan mengalami fluktuasi dan tidak bisa di prediksi secara jelas. Maka dari itu hasil peramalan tersebut, menurut Aulia Ishak (2010:119), salah satu komponen yang mempengaruhi naik turunnya tingkat jumlah tamu menginap adalah pola musiman. Komponen musim menggambarkan pola penjualan yang berulang setiap periode, dimana bisa dijabarkan kedalam faktor cuaca, libur, atau kecenderungan perdagangan. Maka dari itu, tingkat jumlah tamu menginap bisa dipastikan pada saat liburan akan ramai kunjungan wisatawan baik domestik maupun mancanegara

Dari hasil peramalan adalah menggunakan metode single exponential smoothing. Menurut Aulia Ishak (2010:126), pengertian dasar dari metode ini adalah nilai ramalan pada periode $t+1$ merupakan nilai aktual pada periode $t$ ditambah dengan penyesuaian yang berasal dari kesalahan nilai ramalan yang terjadi pada periode tersebut. Metode single exponential smoothing menggunakan rumus $\mathrm{F}_{\mathrm{t}+1}=\mathrm{a} X$ $1+(1-a) F_{t-1}$, dalam peramalan ini alpha (a) yang digunakan dalam metode ini adalah $\mathrm{a}=0.5$, dimana $\mathrm{F} 1=$ peramalan pada periode pertama belum tersedia, maka untuk mengatasi masalah ini dapat dilakukan dengan menetapkan nilai F1 sama dengan nilai data periode pertama (X1).

Pada tahun 2018 diprediksi mengalami fluktuasi, tingkat jumlah tamu menginap paling tinggi terjadi pada bulan Agustus sebanyak 389 orang dan tingkat jumlah tamu menginap paling rendah terjadi pada bulan November sebanyak 119 orang. Ramalan memang tidak selalu tepat $100 \%$ akan tetapi dengan pemilihan metode yang tepat dapat membuat peramalan dengan tingkat kesalahan yang kecil. Grafik ramalan tingkat jumlah tamu menginap pada tahun 2018 dapat dilihat pada gambar 4.

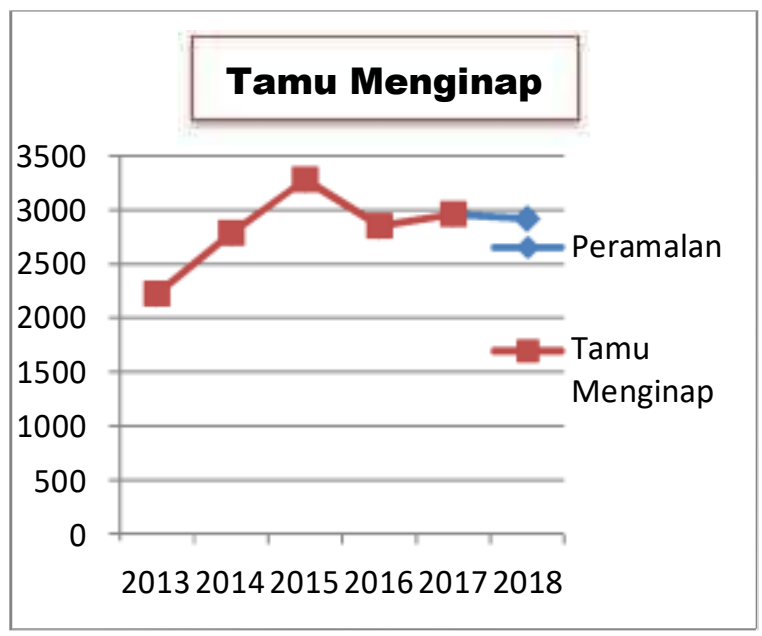

Gambar 4. Grafik ramalan jumlah tamu menginap tahun 2018.

\section{PENUTUP \\ Simpulan}

Berdasarkan hasil penelitian dan pembahasan diatas, maka dapat disimpulkan sebagai berikut. tingkat jumlah tamu menginap di Villa X tahun 2013 2017 mengalami fluktuasi.

Tingkat jumlah tamu menginap pada tahun 2013 sebanyak 2.330 orang dan pada tahun 2014 sebanyak 2.802 orang, mengalami peningkatan sebanyak 472 orang. Tahun 2014 sebanyak 2.802 orang ke tahun 2015 mengalami peningkatan sebanyak 481 orang sehingga tingkat jumlah tamu menginap pada tahun 2015 sebanyak 3.283. Pada tahun 2016 sebanyak 2.913 orang mengalami penurunan 2015 sebanyak 370 orang serta tahun 2017 sebanyak 2.876 orang mengalami penurunan kembali sebanyak 37 orang. Tingkat jumlah tamu menginap paling tinggi terjadi pada tahun 2015 sebanyak 3.283 orang dan tingkat jumlah 
tamu menginap paling rendah terjadi pada tahun 2013 dengan tingkat jumlah tamu menginap sebesar 2.330 orang. Dan Kecenderungan tingkat jumlah tamu menginap dengan menggunakan metode single exponential smoothing di Villa $\mathrm{X}$ tahun 2018 mengalami fluktuasi, dimana bulan Januari diperkirakan jumlah tamu yang datang sebanyak 224 orang, bulan Februari sebanyak 206.75 orang dibulatkan menjadi 207 orang, bulan Maret sebanyak 269.75 dibulatkan menjadi 270 orang, bulan April sebanyak 200 orang, bulan Mei sebanyak 292.25 orang dibulatkan menjadi 292 orang, bulan Juni sebanyak 284.25 orang dibulatkan menjadi 284 orang, bulan Juli sebanyak 333.25 orang dibulatkan menjadi 333 orang, bulan Agustus sebanyak 388.75 orang dibulatkan menjadi 389 orang, bulan September sebanyak 288 orang, bulan Oktober sebanyak 190 orang, bulan November sebanyak 119 orang dan bulan Desember sebanyak 122.25 orang dibulatkan menjadi 122 orang, jadi total keseluruhan yang diperkirakan akan datang sebanyak 2.918.25 orang dibulatkan menjadi 2.918

orang.

\section{Saran}

Berdasarkan simpulan diatas, maka dapat dikemukakan beberapa saran yaitu. Bagi pihak Villa $X$, diharapkan agar dapat lebih memperhatikan kembali tingkat jumlah tamu menginap, sehingga tidak terjadi lagi fluktuasi dimana perusahaan dapat mengantisipasi keadaan dimasa mendatang sehingga risiko kegagalan dan kerugian bisa diminimalkan. Hal ini dapat dilakukan dengan cara meningkatkan jumlah tamu menginap serta memberikan pelayanan yang terbaik agar nantinya para wisatawan yang datang merasa puas dengan pelayanan yang sudah diberikan. dan bagi peneliti selanjutnya, yang melakukan penelitian yang sama diharapkan dapat mengembangkan metode atau menggunakan metode yang lain agar lebih baik untuk hasil yang diperoleh sehingga nantinya dapat dibandingkan dengan penelitian ini.Selain itu, penelitian ini perlu dikembangkan dengan referensi lainnya agar penelitian selanjutnya di bidang pariwisata dapat dikembangkan.

\section{DAFTAR PUSTAKA}

Assauri, Sofjan. 2016. Manajemen Operasi Produksi Pencapaian Sasaran Organisasi Berkesinambungan. Jakarta: Rajawali Pers.

Devi, Emmita. 2016. Pengantar Akomodasi Dan Restoran. Yogyakarta: Deepublish.

Fahmi, Irham. 2014. Manajemen Produksi dan Operasi. Bandung: CV. Alfabeta.

Fuad, M. Christine, H. Nurlela, Sugiarto, Paulus, Y, EP. 2000. Pengantar Bisnis. Jakarta: PT. Gramedia Putaka Utama.

Handoko, Hani T. 2012. Dasar-Dasar Manajemen Produksi Dan Operasional. Yogyakarta: BPFE.

Ishak, Aulia. 2010. Manajemen Operasi. Yogyakarta: Graha Ilmu.

Nasution, Arman Hakim \& Prasetyawan, Y. 2008. Perencanaan dan Pengendalian Produksi. Edisi Pertama. Yogyakarta: Graha IImu.

Render, B. \& Heizer, J. 2005. Manajemen Operasi. Jakarta: Salemba Empat.

Sujerweni, Wiratna. 2014. Metode Penelitian Lengkap, Praktis, dan Mudah Dipahami. Yogyakarta: PT Pusaka Baru.

Supranto, J. 2000. Statistik Teori dan Aplikasi Edisi Keenam. Jakarta: Erlangga.

Undang-undang Republik Indonesia no 10 tahun 2009 tentang Kepariwisataan. 2009. Jakarta.

Wignjosoebroto, Sritomo. 2003. Pengantar Teknik \& Manajemen Industri, Edisi Pertama. Jakarta: Guna Widya 